insisted, against his medical attendant's advice, in making a passage to another port. It should only have been about a 12 hours' run, but when about half way to the destination it came on to blow a gale - as it can in the Mediterranean at very short notice-and the little yacht pitched and rolled to such an extent that the unhappy writer was with difficulty kept in his berth. In such weather he had always been seasick, but now he fully realised the danger in every movement and strain of a clot being detached and the results thereof. He knew fear as he hopes never to know it againhelpless paralysing fear with every lurch of the yacht; he was not sick.

I suppose a belt of any sort is presumed to be beneficial on the theory that sea-sickness is caused by movement or displacement of the viscera, but whatever relief belts may give I don't think that their action on visceral movement has much to do with it. During what we all soon hope to call the late war I saw soldiers accustomed to violent gymnastic exercises, and rough riders whose viscera get a lot of shaking up, quite as sea-sick as anyone else; and a proprietor of a circus in South Africa who takes his company all over the world informed me that his acrobats suffered quite as much at sea as ordinary humanity.

Space will not permit my opening up the wide subject of treatment, but I must say a word about boats. Every man whose business or pleasure takes him continuously backwards and forwards across oceans and seas knows exactly what boats of the lines he travels by have the reputation of being good and comfortable sea-boats; that is, boats that have an easy motion over rather than through a heavy sea, thereby lessening the shock of impact so trying to the sea-sick-boats also which do not unduly roll with that terrible interval at the extreme angle which sailors express by saying "she feels as if she was never comin' back again." Details as to the behaviour of boats at sea are not to be obtained from the clerk in the company's office from whom the passenger books his berth, and the size of a boat is not by any means a guarantee of her comfort in a sea-way. As to yachts, in their behaviour at sea they vary enormously and therefore in their capabilities of producing sea-sickness. All get their reputation, but if even doubtful they are always described to the would-be purchaser as "the finest sea-boat of her tonnage afloat," and often such a high-sounding title as Queen of the Ocean (I hope I am not treading on anyone's toes-I have not Lloyd's latest list) is given when she might be more appropriately christened the Emetic. I am, Sirs, yours faithfully,

Parkstone, Dorset.

HENRY GOODALE.

\section{A QUESTION UNDER THE INFECTIOUS DISEASES NOTIFICATION AC'T.}

7o the Editors of THE LANOET.

Suns, - I received the inclosed letter from the medical officer of health of my district. I should be glad to know : 1. If a medical man must not notify according to his (own) opinion. 2. The fact of no bacillus being found-does this make the case certain, as the swab might be taken too late? 3 . Can the district council refuse payment if the notification s sent in good faith ?-I am, Sirs, yours faithfully,

Upper Pontnewydd, March 27th, 1902.

A. W. Hayles.

$$
\text { [INCLOSURE.] }
$$

Cwmbran, R.S.O., Moumouthshire, Niarch 25th, 1902.

DEAR SIR, - I received a notification signed by your assistant, Dr. Wilson, on March $14 \mathrm{th}^{\circ}$ of a case of diphtheria at Woodside-road, the child's name being Davies. I sent a swab taken from the child's throat child's name being Davies. I sent a swab taken from the child's throat to the Jenner Institute of Preventive Medicine for examination and
the repurt sciss that there was no diphtheria bacillus found. The the repurt Sics that there was no diphtheria bacillus found. The Llantarnam District Council direct me to write to you to say that
under the circumstances you will not be entitled to charge the notification fee of $2 s .6 d$. Yours truly.

$$
\text { W. E. C. MURPHY, }
$$$$
\text { Medical Officer of Health. }
$$

** 1. The medical practitioner must act upon the basis of his own judgment. ${ }^{1}$ There is no other standard of action contemplated or recognised by the Notification Act. Moreover, the medical officer of health has to bear in mind that the general practitioner's opinion is the only thing which enables a bacteriolngical examination to be made. 2. The fact that no diphtheria bacillus was found on one occasion does

1 'The words of the certiticate are, "I he reby certify and declare that in my opinton," $f \mathrm{c}$. not, in our view, justify the extreme step which was taken in this case. The swab may have been imperfectly applied or there may have been other factors militating against a correct result. 3. We are not prepared to give a general reply to this query, but we are strongly of opinion that, assuming there to be no question of bad faith, no sanitary authority which properly comprehends its responsibilities should discourage notification in this fashion. It seems to us that the medical officer of health would have been well advised had he invited the coöperation of the notifying practitioner in securing another specimen for bacteriological examination. If the opinion of a medical practitioner is ruthlessly reduced to $n i l$ as the result of one negative bacteriological examination local sanitary administration will be at a rather low ebb. - ED. L.

\section{CHLOROFORM ANAESTHESIA DURING SLEEP.}

To the Editors of THE LANCET.

Sirs,--In The LANCET of March 29th, p. 911, you describe an article on Chloroform Anæsthesia during Sleep by Dr. N. Stone Scott of Cleveland, Ohio, in which is discussed the question as to whether such a thing is possible without the patient being awakened. I have on two occasions successfully administered chloroform to patients who were asleep, in one case to a youth aged 16 years, and in the other to a child. In the former case the patient was suffering from paraphimosis. Chloroform was administered slowly at the commencement. No struggling was experienced and circumcision was performed. This took place about 3 P.M. and the patient did not wake until next morning when he was greatly surprised to find that the operation was over. In the case of the child the administration of chloroform was equally successful Complete anæsthesia was rapidly produced and an operation was performed.

I have had no failures and my experience is limited to these two cases, but " the admitted rarity of such an occur rence " is my reason for bringing them to notice. I am, Sirs, yours faithfully,

Wolverhampton, April 1st, 1902.

W. R. SOMERSET.

\section{PROFESSIONAL LONGEVITY.}

To the Editors of 'THE LANCET.

Sins, - Apropos of the quotation from the Star in THE LANCET of March 22 nd (p. 856), I think it may interest your readers to know that Mr. Nathaniel Davidson, to whom I was apprenticed in 1852 , will attain the patriarchal age of 97 years on Saturday, March 29th. He became a Licentiate of the Royal College of Surgeons of Edinburgh in 1828 and a Licentiate of the Society of Apothecaries in 1829, and is probably the senior survivor of both institutions. Mr. Davidson, after practising in London for 30 years, became a Licentiate of the Royal College of Physicians in 1861. He is, I am happy to say, in very good health.

I am, Sirs, yours faithfully,

Cavendish-square, W., March 25th, 1902. CHRISTOPHER HEATH.

\section{THE BATTLE OF' THE CLUBS. To the Editors of THE LANCET.}

SIRs,-Ever since I have been in practice-13 years-I have acted as surgeon to the Victory Lodge of Druids, the payment being $4 s$. per member per annum. In July I wrote asking that my salary should be increased to $6 s$. on account of the amount of work to be done and owing to the fact that the position of the members warranted my asking for an increase. The secretary on Sept. 17th wrote stating that the lodge could not accede to my request. The same day I gave notice to terminate my appointment on Dec. 17th. Several neighbouring practitioners were nominated as surgeons for the vacancy but not being satisfied with the secretary's statement that $I$ resigned owing to my refusal to attend members at a distance they referred to me, and on hearing that the 